\title{
EXPLORATION OF VARIOUS INDONESIAN INDIGENOUS PLANTS AS NATURAL COAGULANTS FOR SYNTHETIC TURBID WATER
}

\author{
Hans Kristianto $^{1 *}$, Sylvia Paulina ${ }^{1}$, Jenny Novianti Muliarahayu Soetedjo $^{1}$ \\ ${ }^{1}$ Department of Chemical Engineering, Faculty of Industrial Technology, Parahyangan Catholic \\ University, Ciumbuleuit 94, Bandung 40141, Indonesia
}

(Received: May 2017 / Revised: March 2018 / Accepted: March 2018)

\begin{abstract}
The availability of clean water is one of the biggest global problems, especially in developing countries. The simplest way to treat turbid water is by using coagulation. However, the utilization of chemical coagulants such as alum and ferrum has several drawbacks, including a high sludge volume and negative health impact when the water is consumed. Natural coagulants offer a better option, especially because of their availability, low price, lower sludge volume, and effectiveness comparable with chemical coagulants. In this study we utilize Moringa oleifera, Carica papaya and Leucaena leucocephala seeds, which are indigenous plants in Indonesia, as natural coagulants. An FTIR study was conducted to qualitatively identify the possible active coagulant agent in the seeds. The coagulant performance in removing turbidity of synthetic kaolin water was studied using jar test apparatus at various levels of coagulant dosage and $\mathrm{pH}$. Functional groups of $-\mathrm{OH}, \mathrm{N}-\mathrm{H}, \mathrm{C}=\mathrm{O}$, and primary, secondary and tertiary amides were identified in all the seeds. Neither the dosage nor the $\mathrm{pH}$ had an effect on turbidity removal when M.oleifera was used as the natural coagulant, but did have some effect on papaya and leucaena. The turbidity removal obtained in this study was comparable with other reported results, therefore it can be concluded that these seeds have the potential to be used as natural coagulants.
\end{abstract}

Keywords: Carica papaya; kaolin; Leucaena leucocephala; Moringa oleifera; Turbidity

\section{INTRODUCTION}

Coagulation and flocculation are widely used as primary methods of water treatment. In the coagulation process, various chemical coagulants such as alum, ferrum, polyaluminium chloride (PAC) and polyferrous sulphate (PFS) are usually used. Although these coagulants work effectively, there are some drawbacks, such as a significant change in $\mathrm{pH}$, inefficiency at low temperatures, and potential associated health problems (for example, Alzheimer's and dementia) (Srinivasan et al., 1999). Furthermore, these coagulants are relatively high in cost, and produce a high volume of sludge (Yin, 2010). Due to these drawbacks, efforts have been made to find alternatives, one of these being the utilization of natural coagulants, which may come from animals or plants. Plant-based coagulants have been used for 4000 years (Sutherland et al., 1990), and have now become an alternative water treatment, especially in rural areas (Mbogo, 2008; Pengchai et al., 2012). It is known that plant-based coagulants are safe for human health, low in cost and biodegradable, and that a lower volume of sludge produced compared to chemical coagulants (Yin, 2010).

\footnotetext{
*Corresponding author's email: hans.kristianto@unpar.ac.id, Tel. +62-22-2032655, Fax: +62-22-2032700 Permalink/DOI: https://dx.doi.org/10.14716/ijtech.v9i3.279
} 
In this study, we utilize $M$. oleifera, leucaena and papaya seeds as plant-based natural coagulants to treat synthethic turbid water. They are native plants that can be easily found in Indonesia. $M$. oleifera has been studied intensively by various researchers (Ndabigengesere et al., 1995; Ghebremichael et al., 2006; Amagloh \& Benang, 2009; Beltrán-Heredia \& SánchezMartín, 2009), however leucaena and papaya seeds are relatively unexplored. Yongabi et al. (2011) studied the utilization of whole papaya seeds as a natural coagulant to remove turbidity and fecal bacteria, while Al-Mamun and Basir (2016) used leucaena seed extract as a natural coagulant. However, the effect of various parameters in the utilization of papaya and leucaena seeds as natural coagulants to the coagulation process has not been studied to date. In this study, we explore the effect of seed size, dosage and $\mathrm{pH}$ on the removal of turbidity in synthetic turbid water. The qualitative characterization of the active coagulant agent was also studied using FTIR analysis.

\section{EXPERIMENTAL METHOD}

\subsection{Preparation of Natural Coagulant}

Dried M. oleifera seeds were obtained from a local market in Bandung, West Java, Indonesia, and the de-shelled seeds were used as a natural coagulant. Papaya fruits were also obtained from a local market in Bandung, while the leucaena pods were collected from trees nearby. The flesh of the papaya fruit and the outer part of the leucaena pods were removed to obtain the seeds. These were repeatedly washed to remove impurities, then dried using an oven at $110^{\circ} \mathrm{C}$ until the water content was below $10 \% \mathrm{w}$. The obtained seeds were ground to obtain a powder with a mesh size of $-0+40,-40+50$, and $-50+60$. The powder was stored in a dessicator and used as a natural coagulant without any further treatment. The seed powder was also analysed using FTIR (Shimadzu FTIR 8400, KBr pellet method) to qualitatively observe the possible active coagulant component in the seeds.

\subsection{Coagulation Tests}

Synthetic turbid water was prepared by adding 1 gram of kaolin powder (technical grade) into 1 $\mathrm{L}$ of tap water, followed by mixing at $60 \mathrm{rpm}$ for $20 \mathrm{~min}$ to ensure hydration of the kaolin and

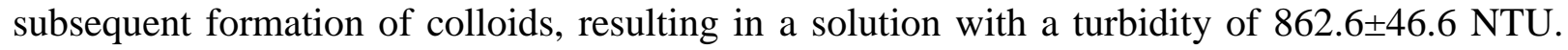
The $\mathrm{pH}$ of the solution was adjusted using $1 \mathrm{M} \mathrm{HCl}$ or $\mathrm{NaOH}$ solution, prior to the jar test experiments. The coagulant seed powder was added at various dosages, and rapidly mixed at $200 \mathrm{rpm}$ for 1 minute, followed by slow mixing at $60 \mathrm{rpm}$ for 30 minutes. These mixtures were then left undisturbed for 1 hour to settle. The turbidity (NTU) of the solution before and after coagulation was measured using a turbiditimeter (Eutech Instruments Turbiditimeter TN-100), and the removal was calculated using Equation 1.

$$
\% \text { removal }=\frac{\text { initial turbidity-final turbidity }}{\text { initial turbidity }} \times 100 \%
$$

The dosage and $\mathrm{pH}$ were varied in the experiment, following the design matrix presented in table 1.

Table 1 Variation of dosage and $\mathrm{pH}$

\begin{tabular}{lccrrr}
\hline \multicolumn{1}{c}{ Variable } & $-\alpha$ & -1 & 0 & +1 & $+\alpha$ \\
\hline Dosage $(\mathrm{g} / \mathrm{L})$ & 0.29 & 0.5 & 1.0 & 1.5 & 1.71 \\
$\mathrm{pH}$ & 8.58 & 9.0 & 10.0 & 11.0 & 11.4 \\
\hline
\end{tabular}

\section{RESULTS AND DISCUSSION}

\subsection{FTIR Analysis}

The FTIR analysis was made to obtain the active functional groups at the surface of the natural coagulants. The spectra presented in Figure 1 show strong and sharp peaks at $3600-3200 \mathrm{~cm}^{-1}$, 
indicating $-\mathrm{OH}$ and $\mathrm{N}-\mathrm{H}$ overlapping stretching vibrations (Betatache et al., 2014), symmetrical, asymmetrical stretches, and bends of $\mathrm{C}-\mathrm{H}$ around 2950,2850 , and $1460 \mathrm{~cm}^{-1}$ respectively (Fatombi et al., 2013; Shak \& Wu, 2014; Janakiraman \& Johnson, 2015). The C=O functional group of carbocylic acids and esters was observed around $1780-1710 \mathrm{~cm}^{-1}$ (Fedala et al., 2015), and peaks at 1650,1540 , and $1240 \mathrm{~cm}^{-1}$ belong to the primary, secondary and tertiary amides, respectively (Wang et al., 2009; Fatombi et al., 2013). The -OH bond in the phenolic structure was observed at a peak of $1270 \mathrm{~cm}^{-1}$ (Bodirlau \& Teaca, 2009), with peaks between $1440-1398 \mathrm{~cm}^{-1}$ indicating $-\mathrm{OH}$ in the plane bends of the carboxylic acid structure (Pearson \& Slifkin, 1972). C-O-C glycosidic bonds of polysaccharides were also observed around 1050$1170 \mathrm{~cm}^{-1}$ (Lammers et al., 2009). These FTIR results show that all the seeds contain active agents that can be used as natural coagulants, especially proteins. It is known that lectin in $M$. oleifera is the active agent in its coagulation (Okuda et al., 2001; Madrona et al., 2010), while the active agents of papaya and leucaena are still unknown. However, it is known that papaya seeds contain $27.8 \%$ w of protein (Marfo et al., 1986a), of which a 23.7\% w fraction is soluble in $5 \% \mathrm{NaCl}$ (globulin) and only $10.9 \%$ is water soluble (albumin) (Marfo et al., 1986b), while leucaena contains $57.8 \% \mathrm{w}$ (dry basis) of protein (Sethi \& Kulkarni, 1994), with a $44.9 \%$ fraction being globulin, and 29.3\% albumin (Sethi \& Kulkarni, 1993).

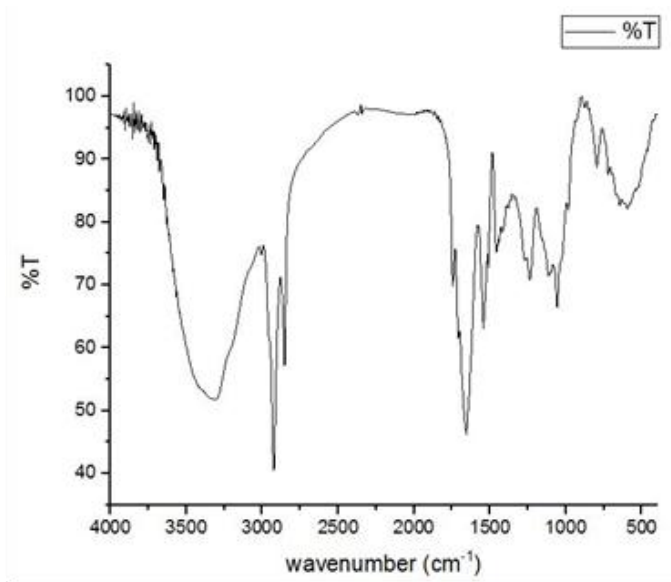

(a)

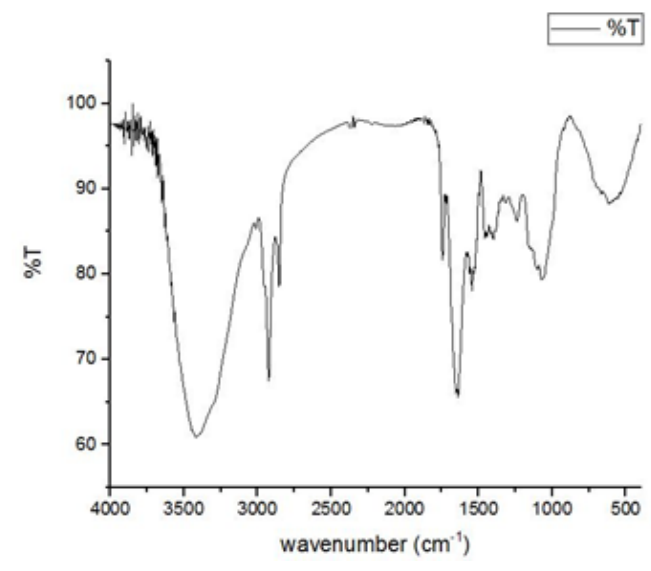

(b)

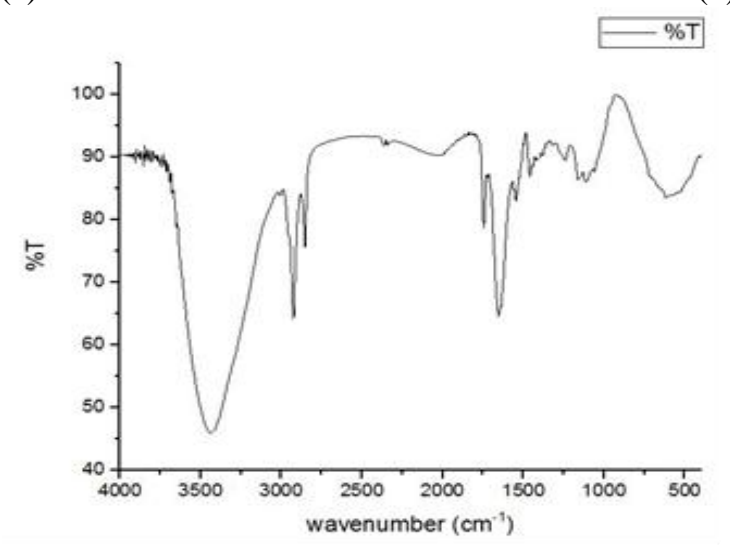

(c)

Figure 1 FTIR spectra of: (a) M. Oleifera; (b) Leucaena; and (c) C. Papaya seeds

\subsection{The Effect of Seed Size on Turbidity Removal}

The effect of seed size on its performance as a natural coagulant is presented in Figure 2. It can be observed that in the case of $M$. oleifera, its unground (whole) seeds gave the highest turbidity removal, while for the papaya seeds, the highest removal was observed at $-40+50$ 
mesh, and leucaena seed size had no effect on turbidity removal. It is known that particle size plays an important role in extraction; the smaller the particle size, the greater the number of compounds that can be extracted (Asep et al., 2008; Gião et al., 2009; Sari \& Velioglu, 2011). However, with smaller seed sizes, compounds other than the active coagulant agent can also be extracted to water, thus contributing to the turbidity measured. We speculate that some compounds, such as carbohydrate and fibre, were dispersed to the water with the small seed size, which led to lower turbidity removal. For further dosage and $\mathrm{pH}$ study, seed size was used at its highest level of turbidity removal, which is whole seeds for $M$ oleifera, and $-40+50$ mesh for leucaena and papaya.

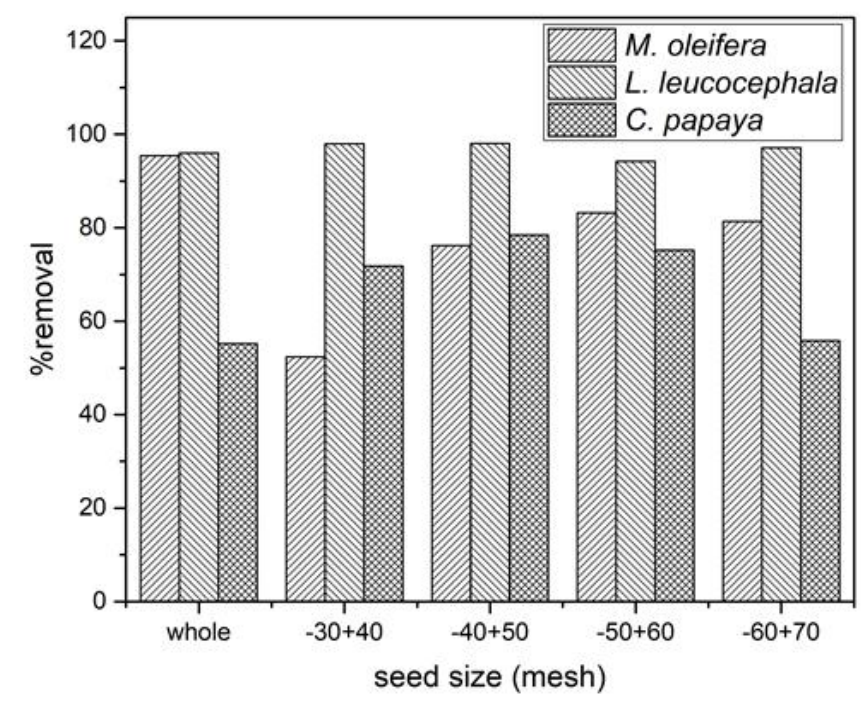

Figure $2 \%$ removal of turbidity with various seed sizes

\subsection{Effect of Dosage and $\mathrm{pH}$ on Turbidity Removal}

The effect of the dosage $(\mathrm{g} / \mathrm{L})$ of various seeds and $\mathrm{pH}$ on turbidity removal is presented in Figure 3. It can be observed that the dosage and $\mathrm{pH}$ did not have any effect on the turbidity removal of $M$. oleifera (Figure 3a.), although there were some changes in turbidity removal when leucaena and papaya were used as the natural coagulants (Figures $3 \mathrm{~b}$ and $3 \mathrm{c}$ ). About $98 \%$ turbidity removal was obtained by $M$. oleifera, regardless of the dosage and $\mathrm{pH}$ of the solution, while leucaena gave $87.6 \%$ removal $(1 \mathrm{~g} / \mathrm{L}, \mathrm{pH} 10)$ and papaya $93.6 \%(1 \mathrm{~g} / \mathrm{L}, \mathrm{pH} 10)$.

The results obtained for the dosage and $\mathrm{pH}$ variation in turbidity removal in this study are in accordance with those obtained by various other researchers. The results obtained by Okuda et al. (2001) showed that $M$. oleifera had high coagulant activity at $\mathrm{pHs}$ above 8 , with constant coagulant activity up to $\mathrm{pH} 12$ (Okuda et al., 2001). Similar results were also reported by Šćiban et al. (2005), showing that at pHs higher than 10, various legumes displayed high coagulant activity (Šćiban et al., 2005).

With regard to the dosage effect, it can be seen that the $M$. oleifera dosage had no effect on turbidity removal, whereas there was an optimum dosage level for leucaena and papaya. The effect of M. oleifera dosage was reported by Pritchard et al. (2010); beyond the optimum coagulant dosage, the coagulation effect became less effective, thus constant $\%$ removal was obtained (Pritchard et al., 2010). Overdosage of coagulant tends to lead to a colloid restabilization effect (Choy et al., 2015); however, this effect is not observed in M. oleifera (Ndabigengesere et al., 1995). Different trends were observed with both leucaena and papaya (Figures $3 \mathrm{~b}$ and $3 \mathrm{c}$ ). At low coagulant dosage, turbidity removal was low due to insufficient coagulating agent (Choy et al., 2015); however, overdosage could lead into colloid 
restabilization. This effect is shown in Figures $3 \mathrm{~b}$ and $3 \mathrm{c}$; with $1.5 \mathrm{~g} / \mathrm{L}$ coagulant dosage turbidity removal decreases.

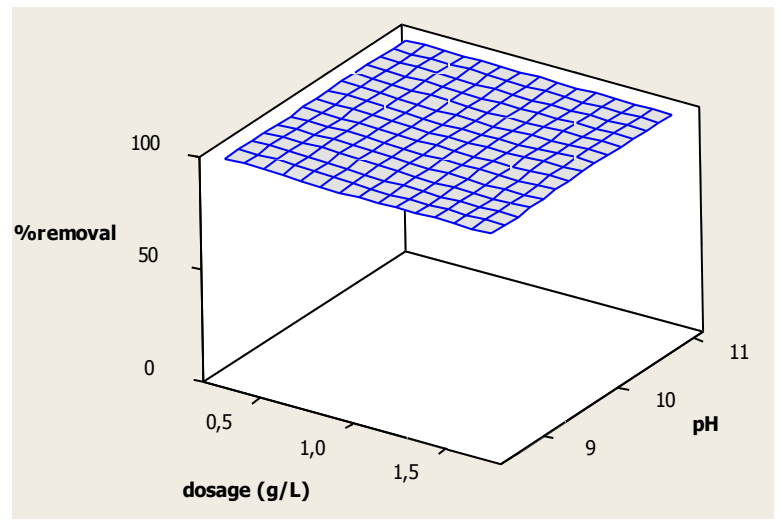

(a)

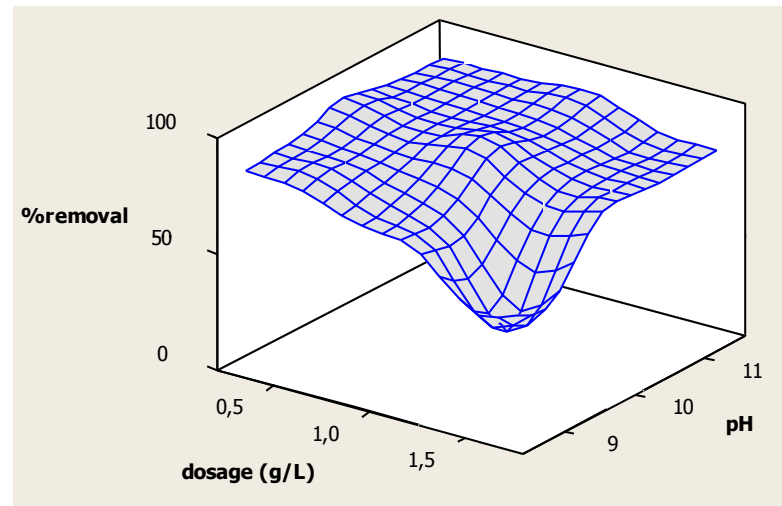

(b)

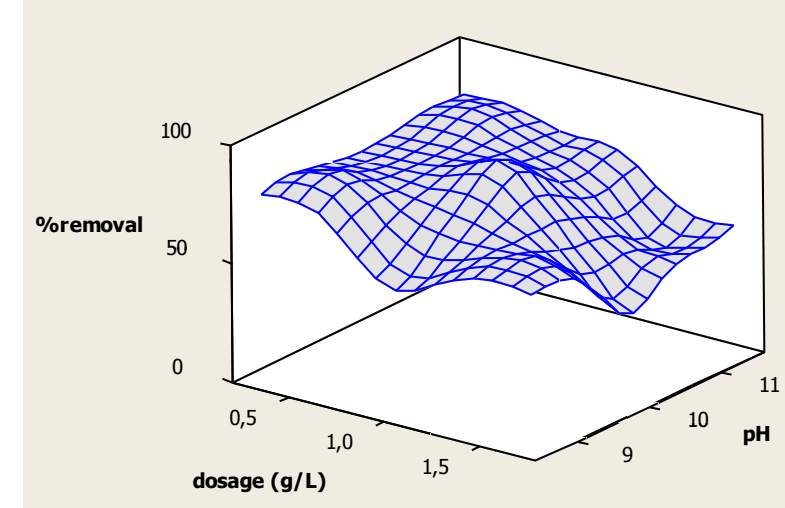

(c)

Figure 3 Effect of dosage (g/L) and pH on turbidity removal: (a) M. Oleifera; (b) leucaena; and (c) papaya

The protein in the seeds was the active coagulant agent in this study. It is known that protein is an amphoteric molecule, which is highly influenced by $\mathrm{pH}$; at a $\mathrm{pH}$ above its isoelectric point, the protein molecule will have negative surface charge. The lectins in M.oleifera have an isoelectric point of 10 (Ndabigengesere et al., 1995). Leucaena protein is high in glutamic acid, leucine and lysine amino acids (Ekpenyong, 1986; Ahmed \& Abdelati, 2009), with isoelectric points of 3.22, 5.98, and 9.74 respectively (Lundbland \& Macdonald, 2010). Papaya seed protein is high in glutamic acid, threonine, proline and leucine (Marfo et al., 1986b), with isoelectric points of 3.22, 5.60, 6.30, and 5.98, respectively (Lundbland \& Macdonald, 2010). The isoelectric point of kaolin is known to be at $\mathrm{pH} 2.8$ (Ndabigengesere et al., 1995), therefore in the experimental $\mathrm{pH}$ range, both colloid and protein had negative surface charges. Consequently, we speculate that adsorption followed by interparticle bridging was the possible mechanism in this study.

A comparison between this work with other studies is shown in Table 2. It can be seen that our results are comparable with others, although the seeds were used directly, without extraction. Even L. leucocephala displayed higher turbidity removal, compared with results obtained by Al-Mamun and Basir (2016). Further study of the effect of various turbidities, sludge volume and the effect of salt extract for leucaena and papaya seeds is needed. 
Table 2 Turbidity removal using various natural coagulants

\begin{tabular}{|c|c|c|c|}
\hline $\begin{array}{c}\text { Initial turbidity } \\
\text { (NTU) }\end{array}$ & Coagulant & $\%$ removal & Reference \\
\hline 450 & M. oleifera seed extract $(\mathrm{NaCl} 1 \mathrm{M})$ & 99.8 & Nkurunziza et al. (2009) \\
\hline 296 & C. papaya seeds & 96.8 & Yongabi et al. (2011) \\
\hline 250 & P. ovata purified seed extract & 95.6 & Ramavandi (2014) \\
\hline \multirow[t]{3}{*}{500} & M. oleifera seed extract $(\mathrm{NaCl} 0.5 \mathrm{M})$ & 99 & \multirow[t]{3}{*}{ Muthuraman and Sasikala (2014) } \\
\hline & P. vulgaris seed extract $(\mathrm{NaCl} 0.5 \mathrm{M})$ & 95 & \\
\hline & S. potatorum seed extract $(\mathrm{NaCl} 0.5 \mathrm{M})$ & 90 & \\
\hline 319 & L. leucocephala seed extract $(\mathrm{NaCl} 1 \%)$ & 76 & Al-Mamun and Basir (2016) \\
\hline \multirow[t]{3}{*}{$862.6 \pm 46.6$} & M. oleifera seed powder & 98.8 & \multirow[t]{3}{*}{ This study } \\
\hline & L. leucocephala seed powder & 87.6 & \\
\hline & C. papaya seed powder & 93.6 & \\
\hline
\end{tabular}

\section{CONCLUSION}

The utilization of $M$. oleifera, leucaena and papaya seeds, which are indigenous plants in Indonesia, as natural coagulants has been studied in this research. From the FTIR spectra, it can be observed that all the seeds contained active coagulant agents, and could be used to treat turbid water. The coagulant dosage $(\mathrm{g} / \mathrm{L})$ and $\mathrm{pH}$ had no effect on the turbidity removal of $M$. oleifera, but some effect was observed when leucaena and papaya seed powder was used as the natural coagulant. The turbidity removal in this study was comparable with the results obtained by other researchers. Further study of the initial turbidiy effect, sludge volume after coagulation, and effect of salt extraction is needed.

\section{REFERENCES}

Ahmed, M.E., Abdelati, K.A., 2009. Chemical Composition and Amino Acids Profile of Leucaena leucocephala Seeds. International Journal of Poultry Science, Volume 8(10), pp. 966-970

Al-Mamun, A., Basir, A.T.A., 2016. White Popinac as Potential Phyto-coagulant to Reduce Turbidity of River Water. ARPN Journal of Engineering and Applied Sciences, Volume 11(11), pp. 7180-7183

Amagloh, F.K., Benang, A., 2009. Effectiveness of Moringa oleifera Seed as Coagulant for Water Purification. African Journal of Agricultural Research, Volume 4(1), pp. 119-123

Asep, E.K., Jinap, S., Tan, T.J., Russly, A.R., Harcharan, S., Nazimah, A.H., 2008. The Effects of Particle Size, Fermentation and Roasting of Cocoa Nibs on Supercritical Fluid Extraction of Cocoa Butter. Journal of Food Engineering, Volume 85(3), pp. 450-458

Beltrán-Heredia, J., Sánchez-Martín, J., 2009. Improvement of Water Treatment Pilot Plant with Moringa oleifera Extract as Flocculant Agent. Environmental Technology, Volume 30(6), pp. 525-534

Betatache, H., Aouabed, A., Drouiche, N., Lounici, H., 2014. Conditioning of Sewage Sludge by Prickly Pear Cactus (Opuntia ficus Indica) Juice. Ecological Engineering, Volume 70, pp. 465-469

Bodirlau, R., Teaca, C.A., 2009. Fourier Transform Infrared Spectroscopy and Thermal Analysis of Lignocellulose Fillers Treated with Organic Anhydrides. Romanian Journal of Physics, Volume 54(1), pp. 93-104

Choy, S.Y., Prasad, K.M.N., Wu, T.Y., Ramanan, R.N., 2015. A Review on Common Vegetables and Legumes as Promising Plant-based Natural Coagulants in Water Clarification. International Journal of Environmental Science and Technology, Volume 12(1), pp. 367-390 
Ekpenyong, T.E., 1986. Nutrient and Amino Acid Composition of Leucaena leucocephala (Lam.) de Wit. Animal Feed Science and Technology, Volume 15, pp. 183-187

Fatombi, J.K., Lartiges, B., Aminou, T., Barres, O., Caillet, C., 2013. A Natural Coagulant Protein from Copra (Cocos nucifera): Isolation, Characterization, and Potential for Water Purification. Separation and Purification Technology, Volume 116, pp. 35-40

Fedala, N., Lounici, H., Drouiche, N., Mameri, N., Drouiche, M., 2015. Physical Parameters Affecting Coagulation of Turbid Water with Opuntia ficus-indica Cactus. Ecological Engineering, Volume 77, pp. 33-36

Ghebremichael, K.A., Gunaratna, K.R., Dalhammar, G., 2006. Single-step Ion Exchange Purification of the Coagulant Protein from Moringa oleifera Seed. Appl Microbiol Biotechnol, Volume 70, pp. 526-532

Gião, M.S., Pereira, C.I., Fonseca, S.C., Pintado, M.E., Malcata, F.X., 2009. Effect of Particle Size Upon the Extent of Extraction of Antioxidant Power from the Plants Agrimonia eupatoria, Salvia sp. and Satureja montana. Food Chemistry, Volume 117(3), pp. 412-416

Janakiraman, N., Johnson, M., 2015. Functional Groups of Tree Ferns (Cythea) using FT-IR: Chemotaxonomic Implications. Romanian J. Biophys., Volume 25(2), pp. 131-141

Lammers, K., Arbuckle-Keil, G., Dighton, J., 2009. FT-IR Study of the Changes in Carbohydrate Chemistry of Three New Jersey Pine Barrens Leaf Litters during Simulated Control Burning. Soil Biology \& Biochemistry, Volume 41, pp. 340-347

Lundbland, R.L., Macdonald, F.M., 2010. Handbook of Biochemistry and Molecular Biology. $4^{\text {th }}$ Edition. Boca Raton: CRC Press

Madrona, G.S., Serpelloni, G.B., Vieira, A.M.S., Nishi, L., Cardoso, K.C., Bergamasco, R., 2010. Study of the Effect of Saline Solution on the Extraction of the Moringa oleifera Seed's Active Component for Water Treatment. Water Air Soil Pollut, Volume 211, pp. 409-415

Marfo, E.K., Oke, O.L., Afolabi, O.A., 1986a. Chemical Composition of Papaya (Carica papaya) Seeds. Food Chemistry, Volume 22, pp. 259-266

Marfo, E.K., Oke, O.L., Afolabi, O.A., 1986b. Some Studies on the Proteins of Carica papaya Seeds. Food Chemistry, Volume 22, pp. 267-277

Mbogo, S.A., 2008. A Novel Technology to Improve Drinking Water Quality using Natural Treatment Methods in Rural Tanzania. Journal of Environmental Health, Volume 70(7), pp. $46-50$

Muthuraman, G., Sasikala, S., 2014. Removal of Turbidity from Drinking Water using Natural Coagulants. Journal of Industrial and Engineering Chemistry, Volume 20, pp. 1727-1731

Ndabigengesere, A., Narasiah, K.S., Talbot, B.G., 1995. Active Agents and Mechanism of Coagulation of Turbid Waters using Moringa Oleifera. Water Research, Volume 29(2), pp. 703-710

Nkurunziza, T., Nduwayezu, J.B., Banadda, E.N., Nhapi, I., 2009. The Effect of Turbidity Levels and Moringa oleifera Concentration on the Effectiveness of Coagulation in Water Treatment. Water Science \& Technology, Volume 59(8), pp. 1551-1559

Okuda, T., Baes, A.U., Nishijima, W., Okada, M., 2001. Isolation and Characterization of Coagulant Extracted from Moringa oleifera Seed by Salt Solution. Water Research, Volume 35(2), pp. 405-410

Pearson, J.F., Slifkin, M.A., 1972. The Infrared Spectra of Amino Acids and Dipeptides. Spectrochimica Acta, Volume 28A, pp. 2408-2417

Pengchai, P., Keawkhun, K., Suwapet, N., 2012. Low-Cost Engineering Techniques in Sustainable Operation of a Rural Clean Water Plant in Thailand. Sci. Tech. and Dev., Volume 31(3), pp. 271-279 
Pritchard, M., Craven, T., Mkandawire, T., Edmondson, A.S., O’Neill, J.G., 2010. A Study of the Parameters Affecting the Effectiveness of Moringa oleifera in Drinking Water Purification. Physics and Chemistry of the Earth, Volume 35, pp. 791-797

Ramavandi, B., 2014. Treatment of Water Turbidity and Bacteria by using a Coagulant Extracted from Plantago ovata. Water Resources and Industry, Volume 6, pp. 36-50

Sari, F., Velioglu, Y.S., 2011. Effects of Particle Size, Extraction Time and Temperature, and Derivatization Time on Determination of Theanine in Tea. Journal of Food Composition and Analysis, Volume 24(8), pp. 1130-1135

Šćiban, M.B., Klašnja, M.T., Stojimirović, J.L., 2005. Investigation of Coagulation Activity of Natural Coagulants from Seeds of Different Leguminose Species. Acta Periodica Technologica, Volume 36(36), pp. 82-87

Sethi, P., Kulkarni, P.R., 1993. Fractionation of Leucaena Seed-kernel Proteins based on their Solubility Characteristics. Food Chemistry, Volume 48, pp. 173-177

Sethi, P., Kulkarni, P.R., 1994. Chemical Composition of Leucaena leucocephala Seeds. International Journal of Food Sciences and Nutrition, Volume 45, pp. 5-13

Shak, K.P.Y., Wu, T.Y., 2014. Coagulation-flocculation Treatment of High-strength Agroindustrial Wastewater using Natural Cassia obtusifolia Seed Gum: Treatment Efficiencies and Flocs Characterization. Chemical Engineering Journal, Volume 256, pp. 293-305

Srinivasan, P.T., Viraraghavan, T., Subramanian, K.S., 1999. Aluminium in Drinking Water: An Overview. Water SA, Volume 25(1), pp. 47-56

Sutherland, J.P., Folkard, G.K., Grant, W.D., 1990. Natural Coagulants for Appropriate Water Treatment: A Novel Approach. Waterlines, Volume 8(4), pp. 30-32

Wang, J.-P., Chen, Y.-Z., Yuan, S.-J., Sheng, G.-P., Yu, H.-Q., 2009. Synthesis and Characterization of a Novel Cationic Chitosan-based Flocculant with a High Watersolubility for Pulp Mill Wastewater Treatment. Water Research, Volume 43, pp. 52675275

Yin, C.-Y., 2010. Emerging Usage of Plant-based Coagulants for Water and Wastewater Treatment. Process Biochemistry, Volume 45, pp. 1437-1444

Yongabi, K.A., Lewis, D.M., Harris, P.L., 2011. Indigenous Plant based Coagulants/disinfectants and Sand Filter Media for Surface Water Treatment in Bamenda, Cameroon. African Journal of Biotechnology, Volume 10(43), pp. 8625-8629 